AUTHOR:

Takunda Y. Chitaka ${ }^{1 *}$ (D)

\section{AFFILIATION:}

'Department of Chemical

Engineering, University of Cape Town, Cape Town, South Africa

* Present address: DSI/NRF/CSIR

Chair in Waste and Society, University

of the Western Cape, Cape Town,

South Africa

\section{CORRESPONDENCE TO:}

Takunda Chitaka

EMAIL:

chitakaty@gmail.com

DATES:

Received: 17 Oct. 2020

Revised: 08 Apr. 2021

Accepted: 08 Apr. 2021

Published: 29 July 2021

\section{HOW TO CITE:}

Chitaka TY. Environmentalism or greenwashing? Responses of South African value chain actors to plastic straw marine pollution. S Afr J Sci. 2021:117(7/8), Art. \#9042. https:// doi.org/10.17159/sajs.2021/9042

\section{ARTICLE INCLUDES:}

$\triangle$ Peer review

囚 Supplementary material

\section{DATA AVAILABILITY:}

$\square$ Open data set

$\square$ All data included

$\square$ On request from author(s)

凶 Not available

$\square$ Not applicable

EDITOR:

Jenni Case iD

\section{KEYWORDS:}

plastic pollution, marine plastic

plastic alternatives, pollution

mitigation, single-use plastic

\section{FUNDING:}

National Research Foundation of South Africa (grant no. 116431)

\title{
Environmentalism or greenwashing? Responses of South African value chain actors to plastic straw marine pollution
}

\begin{abstract}
The increasing global concern surrounding plastic marine pollution has placed a spotlight on the key items identified as major contributors. The subsequent public outcry has forced key value-chain actors - such as brand owners, retailers and restaurateurs - to be seen to be responding to the issue. However, are their responses motivated by a true desire for environmentalism or are actors engaging in greenwashing? In this case study on plastic straws, the brand owners and retailers interviewed are driven by a desire to meet consumer expectations. This desire has led to the substitution of plastic straws with glass, paper and polylactide alternatives. However, the broader environmental implications of the alternatives are rarely considered. This single-minded focus on marine pollution has the potential to result in inadvertent greenwashing as alternative products may result in more harm in other environmental compartments.

\section{Significance:}

- The increasing concern surrounding plastic pollution has placed a spotlight on key items, forcing plastic value-chain actors to respond.

- The broader environmental impacts of the interventions are rarely considered, resulting in the potential for adoption of products which may result in increased harm in other environmental compartments.
\end{abstract}

\section{Introduction}

The accumulation of plastic in the marine environment has been a global concern for many decades as it poses a threat to wildlife, humans and ecosystems. Impacts of plastic pollution on marine life have been well documented and include entanglement, smothering and ingestion. ${ }^{1-5}$ Previous studies have found that $40-80 \%$ of macro(>20 mm in diameter) marine debris is plastic, most of which is associated with food and beverage products such as bottles, lids/caps, bags, drinking straws and polystyrene fragments. ${ }^{6-11}$

The growing concern surrounding the impact of plastic pollution has led to the development of a myriad of policies at city, national and regional levels in an effort to mitigate the problem. ${ }^{12}$ More specifically, an increasing number of policies have been developed which aim to address problematic products that have been identified as major contributors to marine litter. A notable example is the widespread response to the threat posed by plastic bag pollution which began in the early 1990s and has seen many countries implementing interventions which vary in range and scope. ${ }^{13}$ Policy interventions range from taxes or levies on the sale of plastic bags, bans on thin and lightweight bags, and, in some cases, complete bans on the production, import, sale and use of plastic bags. ${ }^{13,14}$ In recent years, a spotlight has been placed on single-use food-related plastic products including utensils and polystyrene containers. In 2018, Jamaica announced a ban on plastic bags, straws and polystyrene food containers, effective from January $2019 .{ }^{15}$ However, the use of straws in medical facilities such as care homes and hospitals was exempted from the ban. Furthermore, bags with dimensions greater than $61 \mathrm{~cm}$ by $61 \mathrm{~cm}$, and those necessary for maintaining public health and safety (e.g. packaging for raw meat, rice and baked goods) were also exempted. Dominica also announced bans on food-related plastic items in 2018, effective from January 2019, including straws, plates, utensils and polystyrene cups and containers. ${ }^{16}$ More broadly, in the same year, the European Union approved a ban by 2021 on single-use plastics which had been identified as major contributors to marine pollution, including straws, cutlery, plates, polystyrene cups and cotton bud sticks. ${ }^{17}$ Furthermore, India made a similar pledge to ban single-use plastics by $2022 .{ }^{18}$ In this case, single-use plastics are defined as 'disposable plastics which are used only once and then thrown away by the user' and which are completely made of plastic (items such as juice cartons with plastic lids would not be included in the definition). ${ }^{19}$

As evidenced above, straws are one of the items which have been the subject of public outcry globally, with many consumer-led campaigns calling for material alternatives or the outright banning of plastic straws. ${ }^{20-22}$ This has led to a multitude of responses from both companies and governments, in an effort to reduce the consumption of plastic straws and subsequent waste generation. Consequently, there has been an increasing popularity of alternative straw materials, both disposable and reusable, which are often touted as more 'environmentally friendly'.

Some major retailers and restaurant chains in South Africa have responded to the rhetoric surrounding plastic straws by choosing to replace them with alternatives (Figure 1). In June 2018, major retailers Pick $n$ Pay and Woolworths announced a set of initiatives to combat plastic pollution to coincide with World Oceans Day and World Environment Day, respectively. ${ }^{23,24}$ These initiatives included the phasing out of plastic straws from stores in favour of paper straws. Later that year, Famous Brands replaced plastic straws with paper straws in all of their franchises. ${ }^{25}$ In October 2018, Coca-Cola Peninsula Beverages, which provides straws to resellers, announced the same shift. ${ }^{26}$ In 2019, following the trends of the aforementioned countries, South Africa announced a proposal to ban straws, citing the ready availability of alternative materials. ${ }^{27}$ 
Whilst Ocean Basket was the first major franchise to respond to the straw issue ${ }^{22}$, they are a good example of the complexity associated with such a decision. Initially, they resolved to eliminate all straws from their restaurants in January 2018. ${ }^{28}$ However, as the year progressed, the franchise started offering paper straws and then announced their intention to start providing straws made from compostable maize starch. ${ }^{29}$ Similarly, Famous Brands announced a shift to paper straws in October 2018, but then switched to polylactide (PLA) straws in July 2019.

Vince and Stoett ${ }^{30}$ warn that the popularity of anti-plastic activism, particularly on social media, may lead to greenwashing by industry. Greenwashing refers to the misleading of consumers on the environmental benefits associated with a company's products, processes or practices. ${ }^{21,31}$ This sentiment is echoed by Stafford and Jones $^{32}$ who suggest that an overemphasis on plastic pollution and mechanisms to address it may lead to corporate greenwashing through providing a distraction from greater environmental threats such as climate change.

The responses of consumer value chain actors to the public outcry against plastic straws and their underlying motivations are explored here, as well as the extent to which the broader environmental impacts associated with interventions were taken into consideration.

\section{Methods}

Primary data were sourced via semi-structured interviews with seven value chain actors: a brand owner, four retailers (which all had in-house brands) and two restaurateurs (Table 1). The interviewees all held senior positions in their firms and played an active role in decision-making. Selection of participants was based on their market share and their role in bringing straws to market and/or directly to consumers. However, accessibility to value chain actors was a limitation, as not all identified actors were willing to participate.

Interview questions were developed based on whether or not the value chain actor had developed a strategy to address the growing concern surrounding straws as a major contributor to plastic pollution. The questions were open ended, allowing for the interviewer to ask probing questions to elicit further information and explore different avenues that arose. Furthermore, the interview protocol allowed for the interviewer to move back and forth between questions based on the participant's responses. The questionnaires are presented in the supplementary material.

Interviews were conducted face-to-face or via electronic communication, depending on the participant's preference. Interview duration was approximately $1 \mathrm{~h}$; the interviews were recorded and later transcribed.

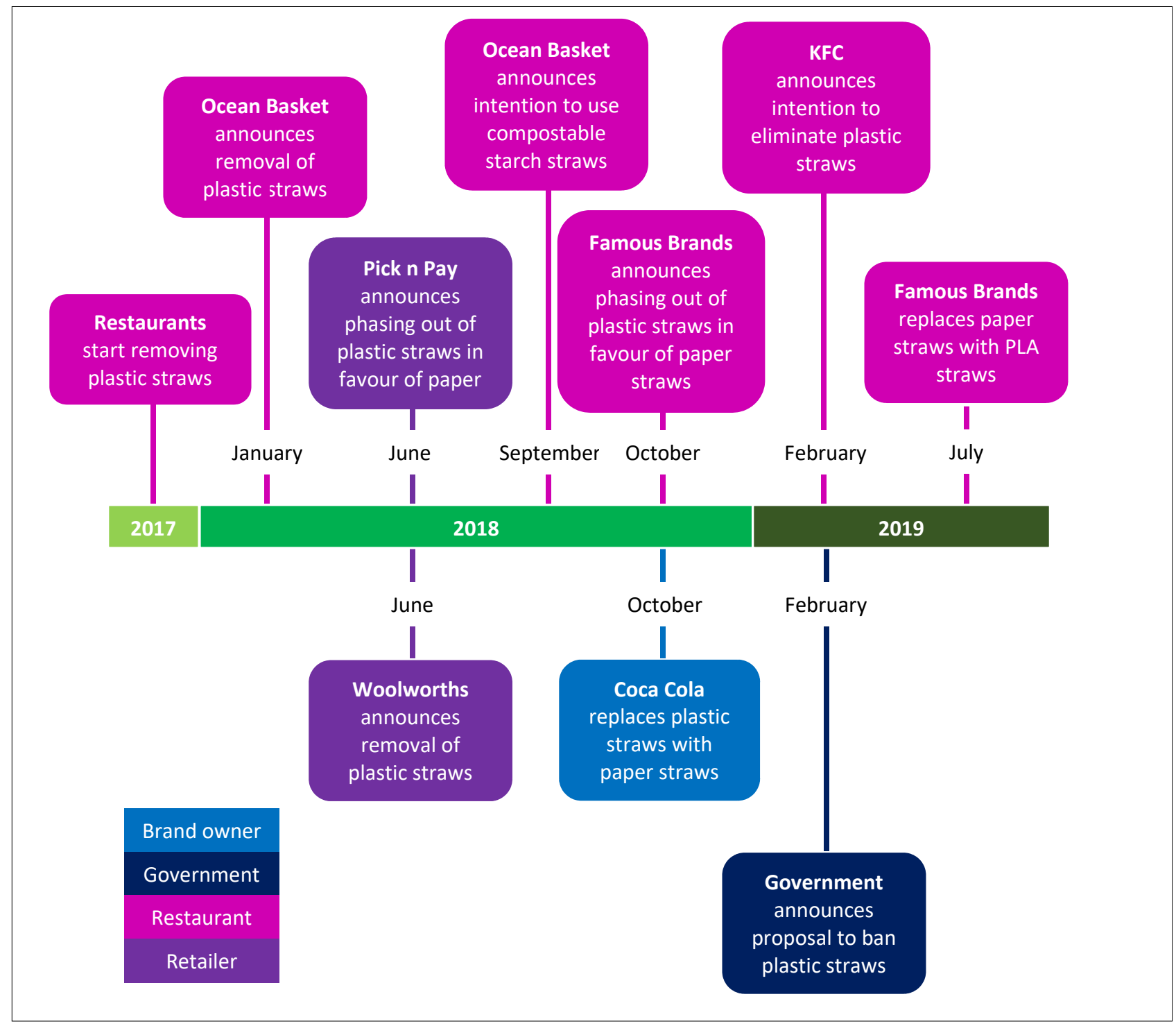

Figure 1: Timeline of responses of value-chain actors in South Africa to plastic straw pollution. 
The study was approved by the University of Cape Town's Engineering and Built Environment Ethics in Research Committee prior to commencement. To maintain anonymity, participant identities are presented in an anonymised form which excludes participant position.

\section{Results and discussion Value chain actor responses}

Of the seven value chain actors consulted, six had shifted away from plastic straws to alternative materials (Table 1). Paper was the most popular alternative amongst retailers, with Retailers $A, B$ and $D$ all replacing plastic with paper straws. Retailer B worked in partnership with their supplier, Brand Owner $C$, which had led to them deciding on paper straws. In addition, Brand Owner C was a supplier for Retailer $D$ that had also reached out to the supplier to discuss a replacement. Unlike other retailers, Retailer $C$ operates a decentralised model with different locations being operated by individual owners. Thus, there was no official stance on straws, with owners being given the freedom to offer any alternative or to continuing using plastic straws. Restaurateur $\mathrm{A}$ replaced plastic straws with PLA straws, whereas Restaurateur B used a combination of paper and glass straws for takeaway and sit-down beverages, respectively.

Table 1: Responses of the value-chain actors interviewed regarding plastic straw alternatives

\begin{tabular}{l|l}
\hline \hline \multicolumn{1}{c|}{ Participant } & \multicolumn{1}{c}{ Response } \\
\hline Retailer A & Paper straws \\
\hline Retailer B & Paper straws \\
\hline Retailer C & No official response; responses left to individual store owners \\
\hline Retailer D & Paper straws \\
\hline Brand Owner C & Paper straws \\
\hline Restaurateur A & PLA straws \\
\hline Restaurateur B & Paper and glass straws \\
\hline
\end{tabular}

\section{Value chain actor motivations}

Amongst retailers, a major motivating factor was the rising unpopularity of straws amongst consumers, due to their high visibility as a contributor to plastic pollution. This was similar to a finding by Haddock-Fraser and Tourell ${ }^{33}$ who analysed corporate environmental activities and found that consumer reputation was a key motivator for companies to undertake environmental activities. Furthermore, as plastic straws currently have readily available material alternatives, they presented a relatively easy opportunity for retailers to be viewed as environmentally responsible to their consumer base.

$$
\text { Everybody just saw it as a quick win! - Retailer D }
$$

This is in line with a suggestion by Stafford and Jones ${ }^{32}$ that the visibility associated with plastic pollution creates an opportunity for 'environmental branding' of individuals and corporations through the publicising of interventions such as product substitution or clean-up activities. In addition, retailers were motivated by a desire to maintain their competitiveness amongst consumers.

Unlike retailers, the restaurateurs cited that they were motivated by their own personal convictions and a desire to reduce their contribution to plastic pollution. Brand Owner $\mathrm{C}$ took an extended producer responsibility approach whereby they viewed it as their responsibility to provide an alternative:

We romanticised the straw and that is why we need to now take responsibility of shifting the consumers' choices away from plastic straws.
Thus, they viewed their decision to switch to paper straws as a way of providing a product that would be less detrimental to the marine environment under current consumer practices (i.e. littering).

\section{Considerations and challenges}

When selecting an alternative, a number of factors were taken into consideration. Cost was cited as a major factor by all actors. In the case of retailers, they had the advantage of economies of scale due to the large quantities they require, which reduced the unit price. In addition, due to the size of their organisations, they were more financially capable of absorbing the extra cost. Restaurateur A cited cost as a major inhibitor to the adoption of reusable straws due to the likelihood of theft by patrons. This was also cited as an issue by Restaurateur B, in addition to breakage of glass straws necessitating replacement. However, they were able to overcome this by partnering with a local glass straw manufacturer to supply their straws, reducing the overall cost of the straws.

The functionality of the straw was a concern to participants, particularly in the case of paper straws. More specifically, the structural integrity of paper straws when immersed in beverages for an extended period of time was of concern, with Retailer A citing that they had received consumer complaints in this regard, necessitating an internal review of locally available paper straws. Restaurateur A also cited this aspect as a consideration in their decision against adopting paper straws as they were perceived as likely to 'disintegrate' in frozen beverages, which are popular in their establishment. However, Retailer B acknowledged that it was a trade-off between straw quality and cost

Hygiene was cited as a concern by Retailer $\mathrm{A}$, when considering reusable straws such as glass or steel. The retailer viewed reusable straws as taking food safety out of their hands whilst still leaving them vulnerable to liability. They used the example of a consumer potentially improperly cleaning a straw bought from the retailer, getting sick from the poor hygiene and blaming the retailer. Restaurateur B also cited hygiene as a concern, whereby glass was seen as more favourable than steel as it was possible to visually inspect the interior for cleanliness.

When it came to the broader environmental impacts associated with straw alternatives, participants did not express consideration of any impacts beyond the potential marine pollution impact. Thus, they selected material alternatives which they perceived to have a low risk of marine pollution impacts through the consideration of their biodegradability. This single-mindedness has the potential to distract from other environmental issues and result in environmental trade-offs being made unknowingly.

As shown in Table 1, paper straws were a popular alternative due to the material's biodegradability in different environments. ${ }^{34}$ From a lifecycle assessment perspective, previous studies comparing plastic vs paper packaging (particularly shopping bags) have commonly found the former to be more favourable in terms of climate change emissions. ${ }^{35-37} \mathrm{~A}$ comparative study of single and reusable straws conducted by Zanghelin et al. ${ }^{38}$ in Brazil found that plastic straws had lower climate change emissions in comparison to paper. However, a similar comparative study conducted in South Africa by Chitaka et al. ${ }^{39}$ found that paper straws had lower climate change emissions than plastic. This was attributed to the use of coal as a primary feedstock during polypropylene plastic production. ${ }^{39}$ Furthermore, paper was found to have the least potential impacts across the majority of categories including freshwater and marine ecotoxicity, particulate matter formation, terrestrial acidification and freshwater eutrophication. However, it is important to note that the broader environmental impacts associated with paper straws were not a consideration for the value chain actors interviewed.

Bio-based plastics (i.e. plastics either partly or wholly derived from biomass), such as PLA, have been rising in popularity as an alternative to traditional plastics. Retailers expressed concern in this regard, citing the amount of misinformation surrounding them, and in particular, the marketing of compostable plastics as biodegradable which gave the impression that they were biodegradable in all environments. This was evidenced in the case of Restaurateur A who cited the perceived biodegradability of PLA in all environments - which is how they had been marketed - as a major motivating factor in their decision. According to 
a study conducted by Greene ${ }^{34}$, PLA did not meet the ASTM D 6691 test requirements to be deemed marine biodegradable. Furthermore, Chamas et al. ${ }^{40}$ found similar polymer surface degradation rates between PLA and polypropylene. The adoption of PLA straws demonstrates the potential for inadvertent greenwashing in the fight against marine pollution.

\section{Conclusions and recommendations}

Value chain actors are under increasing pressure to be viewed as taking action against plastic pollution, including consumer demands and competitive pressure. Although the majority of value chain actors interviewed selected an option which was deemed favourable from a lifecycle perspective (i.e. paper), this was merely coincidental. For larger organisations (retailers and brand owners), the choice of alternative materials was a business decision to find a cost-effective way to respond to consumers' concerns surrounding plastic marine pollution. Whilst smaller value chain actors (restaurateurs) expressed a personal desire to reduce marine pollution, they were more vulnerable to false marketing regarding the environmental impacts associated with a product. This single-minded focus on plastic pollution without the consideration of broader environmental impacts, can potentially lead to inadvertent or deliberate greenwashing.

When developing strategies or interventions to mitigate plastic pollution, it is important to take into consideration the broader environmental implications. This is particularly important in the case of material substitution, as demonstrated by the case of straws. To ensure that value chain actors do not engage in inadvertent greenwashing, their decisions should be based on robust scientific evidence to ensure that their solutions address the problem they are trying to mitigate - in this case marine pollution - and that they are not engaging in burden shifting to other environmental compartments.

Future research is required to investigate the challenges, barriers and drivers for the adoption of environmental assessment tools such as life-cycle assessment in decision-making processes. This will provide insights into how a more holistic perspective to strategy development can be facilitated.

\section{Acknowledgements}

I thank the interviewees for their participation and Prof. Harro von Blottnitz for comments on a draft of the manuscript. This work is based on the research supported in part by the National Research Foundation of South Africa (grant no. 116431).

\section{Competing interests}

I have no competing interests to declare.

\section{References}

1. Derraik JGB. The pollution of the marine environment by plastic debris: $A$ review. Mar Pollut Bull. 2002;44:842-852. https://doi.org/10.1016/S0025$326 \times(02) 00220-5$

2. Kühn S, Bravo Rebolledo EL, Van Franeker JA. Deleterious effects of litter on marine life. In: Bergmann M, Gutow L, Klages M, editors. Marine anthropogenic litter. Cham: Springer; 2015. p. 75-116. https://doi.org/10.1007/978-3-31916510-3_4

3. Gall SC, Thompson RC. The impact of debris on marine life. Mar Pollut Bull. 2015;92:170-179. https://doi.org/10.1016/j.marpolbul.2014.12.041

4. Rochman CM, Browne MA, Underwood AJ, Van Franeker JA, Thompson RC, Amaral-Zettler LA. The ecological impacts of marine debris: Unraveling the demonstrated evidence from what is perceived. Ecology. 2016;97:302-312. https://doi.org/10.1890/14-2070.1

5. Worm B, Lotze HK, Jubinville I, Wilcox C, Jambeck J. Plastic as a persistent marine pollutant. Annu Rev Environ Resour. 2017;42:1-26. https://doi. org/10.1146/annurev-environ-102016-060700

6. Barnes DK, Galgani F, Thompson RC, Barlaz M. Accumulation and fragmentation of plastic debris in global environments. Philos Trans $R$ Soc Lond B Biol Sci. 2009:364:1985-1998. https://doi.org/10.1098/ rstb.2008.0205
7. Andrady AL. Microplastics in the marine environment. Mar Pollut Bull. 2011;62:1596-1605. https://doi.org/10.1016/j.marpolbul.2011.05.030

8. Ryan PG. Litter survey detects the South Atlantic 'garbage patch'. Mar Pollut Bull. 2014;79:220-224. https://doi.org/10.1016/j.marpolbul.2013.12.010

9. Galgani F, Hanke G, Maes T. Global distribution, composition and abundance of marine litter. In: Bergmann M, Gutow L, Klages M, editors. Marine anthropogenic litter. Cham: Springer; 2015. p. 29-56. https://doi. org/10.1007/978-3-319-16510-3 2

10. Weideman EA, Perold V, Arnold G, Ryan PG. Quantifying changes in litter loads in urban stormwater run-off from Cape Town, South Africa, over the las two decades. Sci Total Environ. 2020;724:138310. https://doi.org/10.1016/j. scitotenv.2020.138310

11. Chitaka TY, Von Blottnitz H. Accumulation and characteristics of plastic debris along five beaches in Cape Town. Mar Pollut Bull. 2019:138:451-457. https:// doi.org/10.1016/j.marpolbul.2018.11.065

12. UNEP. Addressing marine plastics: A systemic approach - Stocktaking report United Nations Environment Programme: Nairobi, Kenya, 2018.

13. Xanthos D, Walker TR. International policies to reduce plastic marine pollution from single-use plastics (plastic bags and microbeads): A review. Mar Pollut Bull. 2017;118:17-26. https://doi.org/10.1016/j.marpolbul.2017.02.048

14. United Nations Environment Programme (UNEP). Single-use plastics: A roadmap for sustainability. UNEP; 2018. Available from: https://www.unep. org/resources/report/single-use-plastics-roadmap-sustainability

15. Jamaica Information Service. Plastic bags, straw and polystyrene ban [webpage on the Internet]. c2018 [cited 2019 Jan 02]. Available from: https:// jis.gov.jm/information/get-the-facts/plastic-bags-straw-and-polystyreneban/

16. Government of the Commonwealth of Dominica. Budget address 2018-2019: From survival, to sustainability and success: A resilient Dominica [webpage on the Internet]. c2019 [cited 2019 0ct 30]. Available from: https://finance. gov.dm/budget/budget-addresses/file/27-budget-address-2018-2019-fromsurvival-to-sustainability-and-success-a-resilient-dominica

17. European Parliament. Plastic oceans: MEPs back EU ban on throwaway plastics by 2021 [press release]. c2018 [cited 2018 0ct 10]. Available from: http://www.europarl.europa.eu/news/en/press-room/20181018IPR16524/ plastic-oceans-meps-back-eu-ban-on-throwaway-plastics-by-2021

18. Withnall A. India makes 'unprecedented' pledge to ban all single-use plastic by 2022. Independent. 2018 June 06 [cited 2018 0ct 30]. Available from: https://www.independent.co.uk/news/world/asia/india-plastic-ban-2022single-use-narendra-modi-world-environment-day-a8385966.html

19. Directorate General of Shipping, Mumbai. Addendum no. 1 to DGS Order 5 of 2019. Prohibition on the use of single use plastics on-board merchant ships. 2020 January 08. Available from: https://www.gard.no/Content/28994806/ India\%20Single-use\%20plastic\%20-\%20FINAL\%20Addendum\%201\%20 to\%20DGS\%200rder\%205\%20of\%202019.pd

20. Gibbens S. A brief history of how plastic straws took over the world. National Geographic. 2019 January 03 [cited 2019 Apr 14]. Available from: https:// www.nationalgeographic.com/environment/2018/07/news-plastic-drinkingstraw-history-ban/

21. Viera JSC, Marques MRC, Nazareth MC, Jimenez PC, Castro ÍB. On replacing single-use plastic with so-called biodegradable ones: The case with straws. Environ Sci Policy. 2020;106:177-181. https://doi.org/10.1016/j. envsci.2020.02.007

22. Broll Property Intel. SA retail snapshot Q2: 2019. Johannesburg: Broll Property Group; 2019.

23. Pick $n$ Pay. Pick $n$ Pay announces set of focused initiatives to reduce plastic waste [webpage on the Internet]. c2018 [cited 2018 0ct 10]. Available from: http://www.picknpay.co.za/news/pick-n-pay-supports-world-oceans-day

24. Woolworths Holdings Limited. Woolworths announces zero packaging waste to landfill vision [webpage on the Internet]. c2018 [cited 2018 0ct 30]. Available from: https://www.woolworthsholdings.co.za/woolworthsannounces-zero-packaging-waste-to-landfill-vision/

25. Staff reporter. Wimpy, Steers, Debonairs will be free from plastic straws by December. IOL Business Report. 2018 October 29. Available from: https:// www.iol.co.za/business-report/companies/wimpy-steers-debonairs-will-befree-from-plastic-straws-by-december-17684688 
26. Ramphele L. Coca-Cola goes green launches 'World Without Waste' campaign. Cape Talk. 2018 October 10 [cited 2019 Mar 17]. Available from: http://www.capetalk.co.za/articles/322417/coca-cola-goes-green-launchesworld-without-waste-campaign

27. Talks underway on the last straw. SAnews.gov.za. 2019 February 27 [cited 2019 Aug 19]. Available from: https://www.sanews.gov.za/south-africa/ talks-underway-last-straw

28. Pillay K. \#StopSucking: SA restaurants say 'No to straws!' News24. 2018 January 11 [cited 2018 0ct 30]. Available from: https://www.news24.com/ news24/travel/stopsucking-sa-restaurants-say-no-to-straws-20180111

29. Ramphele L. Ocean basket introducing compostable straws. Cape Talk. 2018 September 13 [cited 2019 Mar 17]. Available from: http://www.capetalk. co.za/articles/319161/ocean-basket-introducing-compostable-cornstarchstraws

30. Vince J, Stoett P. From problem to crisis to interdisciplinary solutions: Plastic marine debris. Mar Policy. 2018;96:200-203. https://doi.org/10.1016/j. marpol.2018.05.006

31. Ramus CA, Montiel I. When are corporate environmental policies a form of greenwashing? Bus Soc. 2005;44:377-414. https://doi. org/10.1177/0007650305278120

32. Stafford R, Jones PJS. Ocean plastic pollution: A convenient but distracting truth? Mar Policy. 2019;103:187-191. https://doi.org/10.1016/j. marpol.2019.02.003

33. Haddock-Fraser JE, Tourelle M. Corporate motivations for environmental sustainable development: Exploring the role of consumers in stakeholder engagement. Bus Strateg Environ. 2010;19:527-542. https://doi. org/10.1002/bse.663
34. Greene J. Biodegradation of biodegradable and compostable plastics under industrial compost, marine and anaerobic digestion. Ecol Pollut Environ Sci. 2018;1:13-18.

35. James K, Grant T. LCA of degradable plastic bags. In: Proceedings of the 4th Australian LCA Conference; 2005 February 23-25; Sydney, Australia. Australian Life Cycle Assessment Society; 2005. p. 1-17.

36. Sevitz J, Brent AC, Fourie AB. An environmental comparison of plastic and paper consumer carrier bags in South Africa: Implications for the local manufacturing industry. S Afr J Ind Eng. 2012;14:67-82. https://doi. org/10.7166/14-1-299

37. KimmelRM, Cooksey KD, Littman A, Ally S, Lebanon TN. Life cycle assessment of grocery bags in common use in the United States. Environmental Studies 6. Clemson, SC: Clemson University Press; 2014. Available from: https:// tigerprints.clemson.edu/cgi/viewcontent.cgi?article $=1006 \&$ context $=$ cudp_ environment

38. Zanghelini GM, Cherubini E, Dias R, Kabe YHO, Delgado JJS. Comparative life cycle assessment of drinking straws in Brazil. J Clean Prod. 2020;276:123070. https://doi.org/10.1016/j.jclepro.2020.123070

39. Chitaka TY, Russo V, Von Blottnitz H. In pursuit of environmentally friendly straws : A comparative life cycle assessment of five straw material options in South Africa. Int J Life Cycle Assess. 2020;25:1818-1832. https://doi. org/10.1007/s11367-020-01786-w

40. Chamas A, Moon H, Zheng J, Qiu Y, Tabassum T, Jang JH, et al. Degradation rates of plastics in the environment. ACS Sustain Chem Eng 2020;8(9):34943511. https://doi.org/10.1021/acssuschemeng.9b06635 